\title{
PARE preliminary analysis of ACARE FlightPath 2050 environmental impact goals
}

\author{
Oleksandr Zaporozhets ${ }^{1} \mathbb{C} \cdot$ Volodymyr Isaienko $^{1} \cdot$ Kateryna Synylo $^{1}$
}

Received: 6 October 2020 / Revised: 13 May 2021 / Accepted: 9 June 2021 / Published online: 5 July 2021

(c) Deutsches Zentrum für Luft- und Raumfahrt e.V. 2021

\begin{abstract}
European aviation plays a key role in serving society's needs for safe, secure and sustainable mobility in Europe and all over the world. Its impact on European economy is significant and must be sustained. Environmental protection is and will continue to be a key driver for the aviation industry as a whole. Meeting community expectations on aircraft noise, engine emission and fuel/energy consumption has always presented a challenge to aircraft and engine manufacturers and to those involved in airport planning and air traffic management. The paper describes the current points of the EU civil aviation on a way to ACARE FlightPath 2050 Challenge 3 goals, defined in PARE project at mid-term stage.
\end{abstract}

Keywords ACARE $\cdot$ FlightPath 2050 goals $\cdot$ Environmental protection

$\begin{array}{ll}\text { Abbreviations } \\ \text { ACARE } & \text { Advisory Council for Aeronautics Research in } \\ & \text { Europe } \\ \text { AN } & \text { Aircraft Noise } \\ \text { APU } & \text { Auxiliary Power Units } \\ \text { ATS } & \text { Air Transportation System } \\ \text { CAEP } & \text { Committee on Aviation and Environment } \\ & \text { Protection } \\ \text { CRL } & \text { Commercial Readiness Level } \\ \text { FAA } & \text { Federal Aviation Administration } \\ \text { GHG } & \text { Green-House Gas } \\ \text { ICAO } & \text { International Civil Aviation Organization } \\ \text { LAQ } & \text { Local Air Quality } \\ \text { NASA } & \text { National Aeronautics and Space Administration } \\ \text { nvPM } & \text { Non-volatile Particulate Matter } \\ \text { PM } & \text { Particulate Matter } \\ \text { SRIA } & \text { Strategic Research and Innovation Agenda } \\ \text { TRL } & \text { Technology Readiness Level } \\ \text { UAM } & \text { Urban Air Mobility } \\ \text { UAS } & \text { Unmanned Aircraft System } \\ \text { UTM } & \text { Unmanned Aircraft System Traffic } \\ & \text { Management }\end{array}$

Oleksandr Zaporozhets

zap@nau.edu.ua

1 National Aviation University, 1, Liubomyra Huzara Avenue, Kyiv 03058, Ukraine

\section{Introduction}

Aviation is recognized as one of the top advanced technology sectors in Europe and generates innovation that benefits society at large far beyond its direct operational sphere. It provides close to 12 million skilled jobs, directly and indirectly, and contributes over 700 billion Euros to Europe's gross domestic product [1]. Home to some 400 airlines and nearly 700 airports, European aviation plays a key role in serving society's needs for safe, secure and sustainable mobility in Europe and all over the world.

EU aerospace research towards ACARE (Advisory Council for Aeronautics Research in Europe) goals faces several challenges, predefined in five specific groups in Strategic Research and Innovation Agenda (SRIA) Flightpath 2050 (FP2050) [2]. Environmental protection in conditions of big number of impacting factors is and will continue to be a key driver for the aviation industry as a whole. The challenge with respect to the environment is to reduce continuously the impact on the global and local environment in the face of continuing expansion in demand for air transportation. This expansion today is covering not only the Air Transportation System (ATS) as a whole, but the Unmanned Aircraft System (UAS) operations within UTM (Unmanned Aircraft System Traffic Management) and Urban Air Mobility (UAM), it will also put pressure on existing energy supplies. In 2050 aircraft technologies and operational procedures available allow a sufficient reduction in ATS contribution to global and local emissions into atmosphere, and the reduction of 
perceived noise of flying aircraft. These are relative to the design and operational capabilities of typical new aircraft in 2000 (Table 1).

ACARE will continue to foster the need to monitor achievements and progress on the SRIA objectives [2]. As an example, in 2015 the ACARE working group on energy and environment estimated that the EU aviation sector had secured an overall $38 \%$ reduction in $\mathrm{CO}_{2}$ per passengerkilometer against a goal of 50\% reduction goal for 2020 . Similarly, technical solutions showed a potential reduction of $37 \%$ in perceived noise has been achieved against a goal of $50 \%$, also by 2020 . While this represents significant progress, effort must be further strengthened to meet the even more challenging goals for noise, global and local emissions set for 2050 [1].

\section{Air traffic and correspondent impact on environment forecasting}

There is evident basic assumption that the impact on environment from aviation sector is fully dependent on the traffic volume in air transportation. Second point is a structure of the aircraft fleet used for air transportation with their specific environmental performances. Concerning the air traffic in Europe it is little bit less growing than the a world as a whole, but differences between the regions exists in Europe also- the same as the differences between ICAO predefined regions around the world. European regional air traffic in 2019 was rising at the end of the second decade of the XXI century $\sim 6 \%$ annually. In 2017, 1043 million people in the EU traveled by air, an increase of $7.3 \%$ compared with 2016 , and $6.7 \%$ increase in 2018 (6.4\% increase globally) - air travel growth has eased in comparison to the strong upward trend seen in 2017, but still continue to go along Regulation and Growth Forecast (Fig. 1). Strong and broad-based traffic growth in 2017 across all market segments finally took European flight totals over the 2008 peak, to 10.6 million. Indeed, even $4 \%$ growth in flights in 2017 looks modest compared to almost twice that reported for passengers or passenger$\mathrm{km}$. European airlines saw traffic rise 5.6\% in June 2019 compared to June 2018, with overall estimated flight growth for 2019 at $1.1 \%$ [3]. Capacity climbed $4.5 \%$ and load factor rose $1 \%$ percentage point to $87.9 \%$. The growth was certainly supported by strong demand and has brought traffic back to the most-likely scenario from the 2013 forecast (after double-dip decline in 2008-Fig. 1). Current COVID-19 crisis impact sufficiently reduced air traffic (on $\sim 60 \%$ in Europe at 2020) and slowed down the development of the aviation sector including the aircraft production around the world. This impact is not considered in an article definitely.

All such forecasts in flight traffic, and accordingly—airport operational capacity limitations, enroute congestion

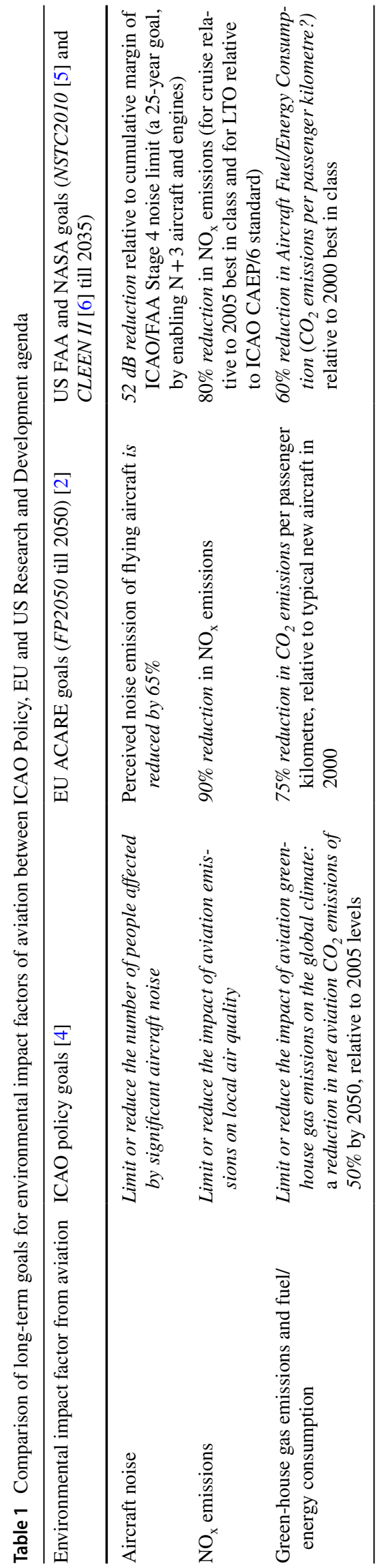




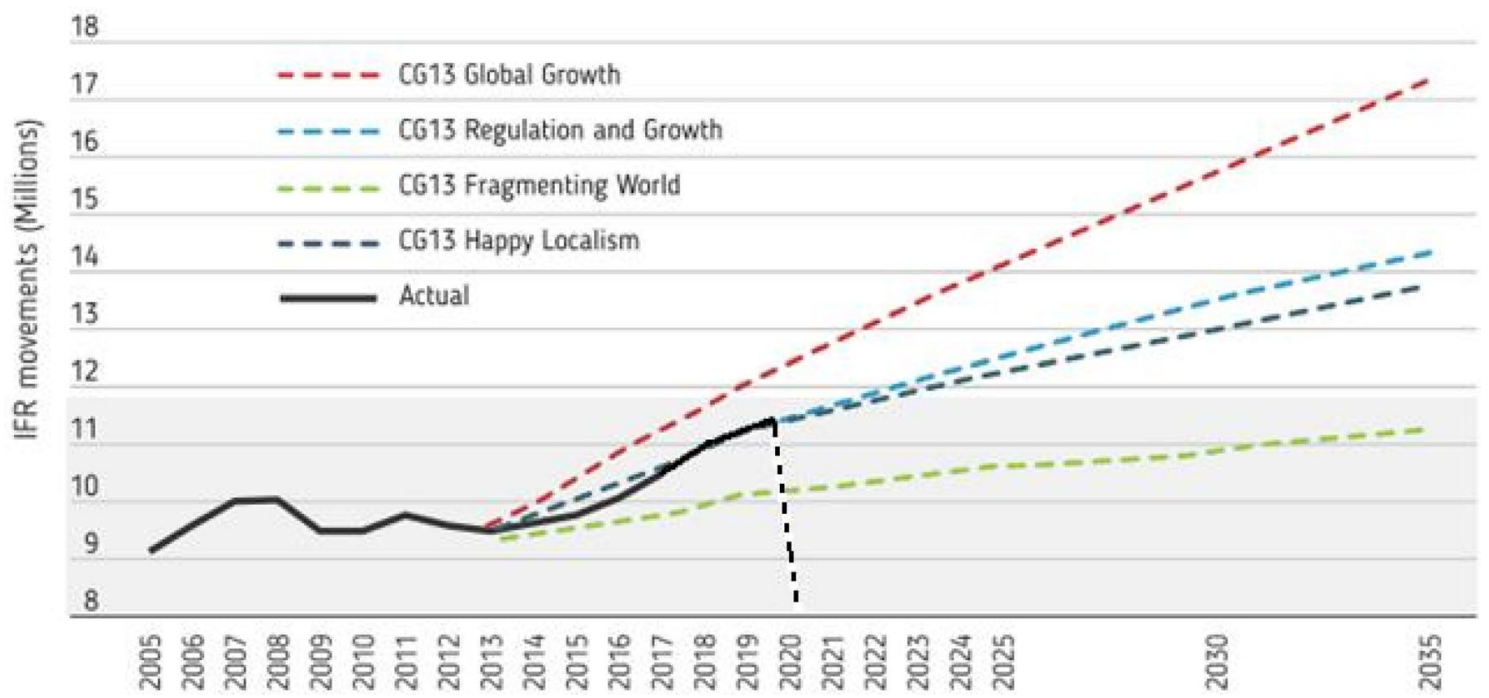

Fig. 1 In 2017-2019, strong growth saw traffic back on the most-likely scenario from the 2013 forecast, modified from [7]

provide the conditions for a growth of impact of aviation on environment. The Challenges of Growth 2018 environment report [6] describes the background and impact in more detail. It also begins to address some of the adaptation measures that are available.

The local environment agenda for aviation is driven largely by noise and occasionally by local air quality impacts, whereas the national and international agenda is primarily focussed on climate change and carbon dioxide emissions. In carrying out its responsibilities, ICAO and its Member States will strive to limit or reduce these dominant and prioritised impact factors (Table 1).

Meeting community expectations on aircraft noise, engine emission and fuel/energy consumption has always presented a challenge to aircraft and engine manufacturers and to those involved in airport planning and air traffic management. To achieve these targets, all (governmental and industrial) stakeholders agreed to closely work together along with a four-pillar strategy:

- Improved technology, including the deployment of sustainable low-carbon fuels;

- More efficient aircraft operations;

- Infrastructure improvements, including modernized air traffic management systems;

- Actions within the aviation sector to adapt and develop resilience to the current and future impacts of climate change

- A single global market-based measure, to fill the remaining emissions gap.

Continued efforts may stabilize aircraft noise (AN) exposure of EU population by 2035-2040, but it will continue to be a key challenge in aviation sector. AN exposure, if to be more truthful, has stabilized over the past decade by the implementation of ICAO Balance Approach to AN management and first of all by sufficient improvements in making the aircraft fleet quieter. The total EU population inside the $L_{\text {den }}$ and $L_{\text {night }}$ contours decreased by only $2 \%\left(L_{\text {den }}\right)$ and $1 \%\left(L_{\text {night }}\right)$ between 2005 and 2014 , to reach 2.52 and 1.18 million people in 2014, and 2.58 and 0.98 million people in 2017 respectively (Fig. 2, [8]). In 2020 the number of exposed by noise population will be reduced dramatically because of huge reduction in air traffic.

In latest inventory assessments an aviation sector represented $13 \%$ of all transport and $3 \%$ of the total EU greenhouse gas (GHG) emissions, representing $22 \%$ of global aviation's GHG emissions. Due to fleet renewal, emissions of $\mathrm{GHG}$ and $\mathrm{NO}_{\mathrm{x}}$ have been relatively stable between 2005 and 2014 (Fig. 3). Similar to noise exposure the reduction in GHG and LAQ emission from aviation sector in 2020 will be dramatic also. However, the nvPM emissions are expected to increase over the next 20 years (on 25\% till 2040) if engine technology remains as it is today [8].

The EU plays a leading role in international efforts to limit climate change, and increased its climate finance contributions to $€ 20.2$ billion in 2016 , - much more is expected in following decade till 2030 as declared by Europe Green Deal in 2019. This is backed up by a legal commitment and framework at EU level to reduce GHG emissions, increase the use of renewable energy and improve energy efficiency. The climate protection targets for 2020, which the EU is on track to meet (with adequate contribution from aviation sector), and 2030 are shown below [8]:

2020

$20 \%$ cut in GHG emission (from 1990 levels); 


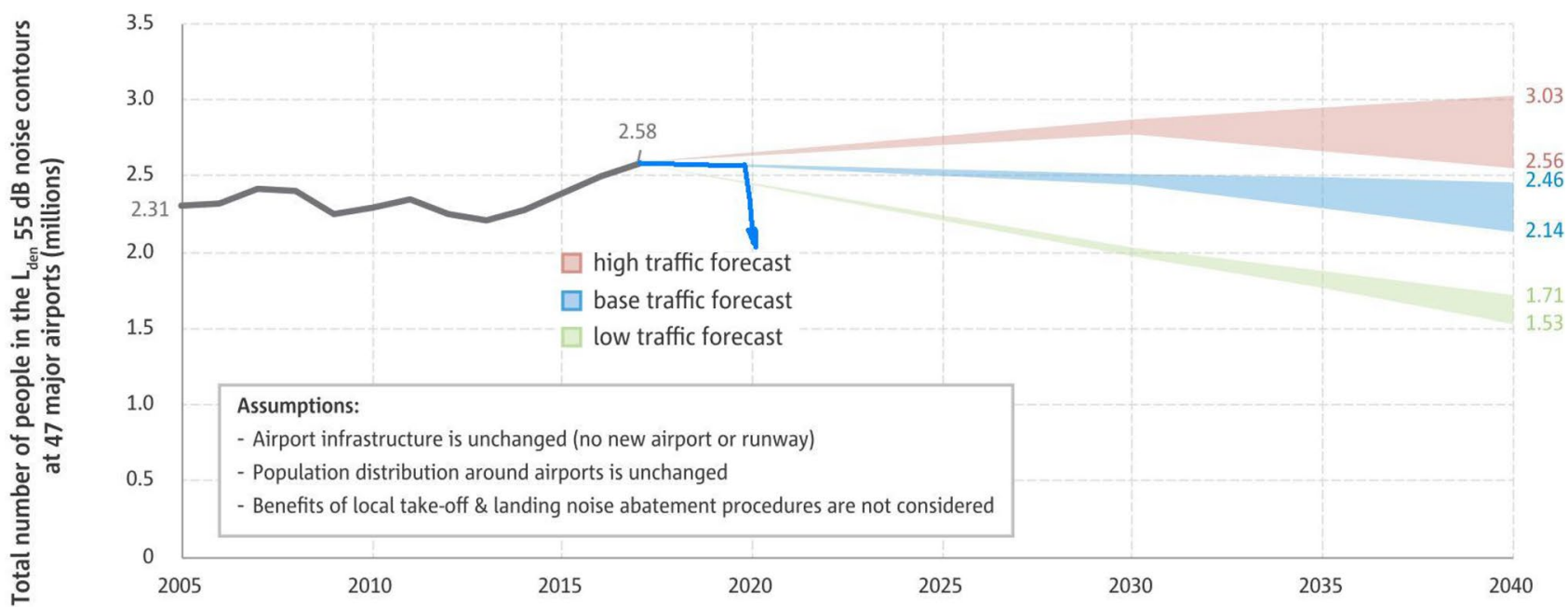

Fig. 2 Fleet renewal could stabilise average noise levels at today's 47 major airports by 2030 [8]

Fig. 3 Emissions are steadily increasing again since 2013: a $\mathrm{CO}_{2}, \mathbf{b ~} \mathrm{NO}_{\mathrm{x}}$ will increase further, but advanced engine combustor technology could help curb their growth after $2030[8]$

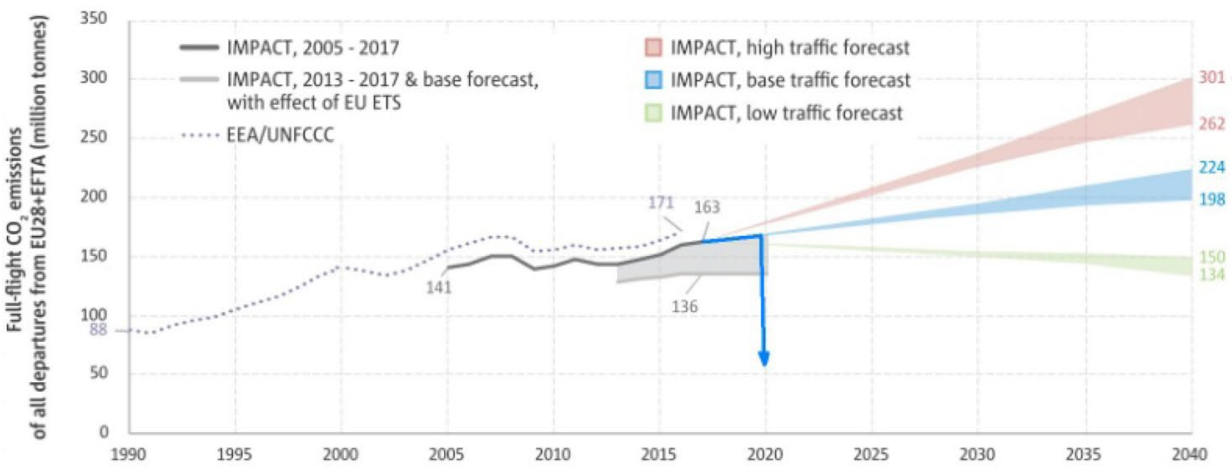

a)
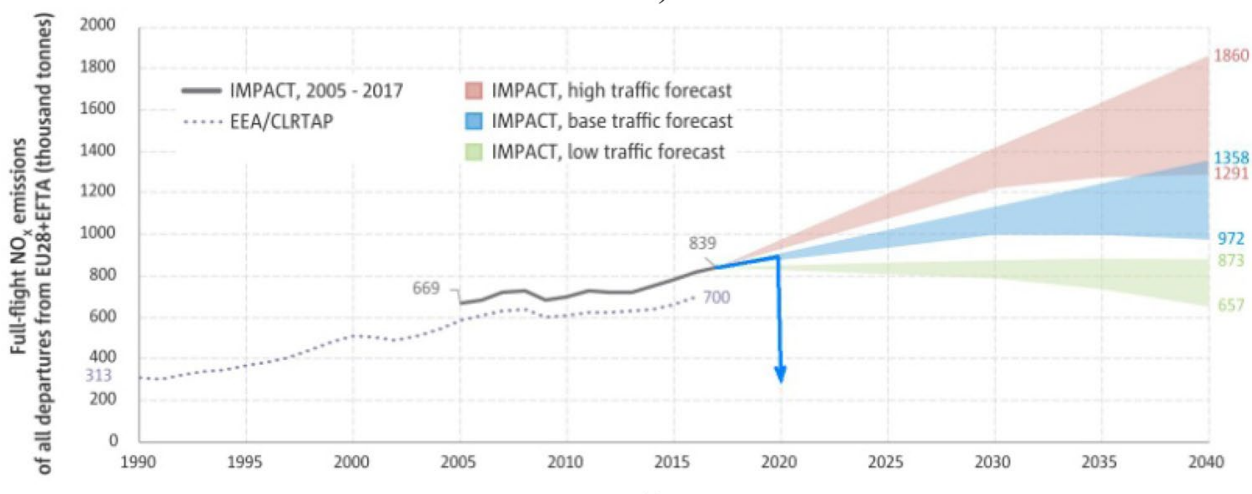

b)

$20 \%$ of EU energy from renewables;

$20 \%$ improvement in energy efficiency;

2030

$\sim 40 \%$ cut in GHG emission (from 1990 levels);

$32 \%$ of EU energy from renewables;

with an upwards revision clause by 2023

$32.5 \%$ improvement in energy efficiency,

with an upwards revision clause by 2023
The EU has also agreed on a '2050 low carbon economy' roadmap that suggests the following targets:

2040

$60 \%$ cut in GHG emission (from 1990 levels);

2050

80\% cut in GHG emission (from 1990 levels), including a $60 \%$ reduction in transport emissions. 
To achieve climate neutrality, a $90 \%$ reduction in transport emissions is needed by 2050 , as defined in the new EU Green Deal proposal (2019). Automated and connected multimodal mobility will play an increasing role, together with smart traffic management systems-ATS, UTM and UAM enabled by digitalisation, and consequently air transport should become drastically less polluting, especially in cities.

It is clear from available studies that these goals cannot all be achieved using evolutions of currently available technologies in aircraft design and operation. Research and innovation for evolutionary aircraft development will drive progress in environmental performance to be on track towards the FP2050 goals. Fuel efficiency improvement of the aircraft in flight will still being a driver for their future developments, concentrating on further less fuel consumption technologies of the engines, cleaner and smarter aerodynamics for drag reduction and lift forces rise, and on reduction of aircraft empty weight. Changes will be introduced in new aircraft or by retrofit into the growing civil aerospace fleet. It is also essential that such technology roadmap and its implementation must continue to receive support through government policy and that it remains a priority for European society (Fig. 4).

To achieve the FP2050 goals, step changes in aircraft configuration and operation (including alternative energy sources) will be required-currently envisaged evolutions will not be sufficient [1]. Changes in aircraft configuration may concern as on more traditional Tube-and-Wing $(\mathrm{T}+\mathrm{W})$ technology, so as Blended-Wing-Body (BWB) configuration. There are many advantages for long-range flying BWB were found in comparison with $\mathrm{T}+\mathrm{W}$ aeroplane: Takeoff Gross Weight $\sim 15 \%$ less (for empty weight $12.3 \%$ lower), Lift-toDrag Ratio 20\% higher, Fuel-Burn 27.5\% lower, Required Thrust 27\% lower, and Operating Cost $13 \%$ lower [9]. In addition for BWB a cumulative reduction of certification noise levels up to $40 \mathrm{~dB}$ and GHG emission on $80 \%$ is possible to expect, which are necessary for reaching the European and US 2050 goals (Table 1). When the BWB is sized with a similar range and payload capacity as the 737-800, NASA's 2005 best in class single-aisle jet, the BWB again achieved NASA's $N+2$ goals [10]. Operational changes are expected mostly due to new on-board navigational and air
Fig. 4 The goals and action areas for Challenge 3 of the ACARE perspectives

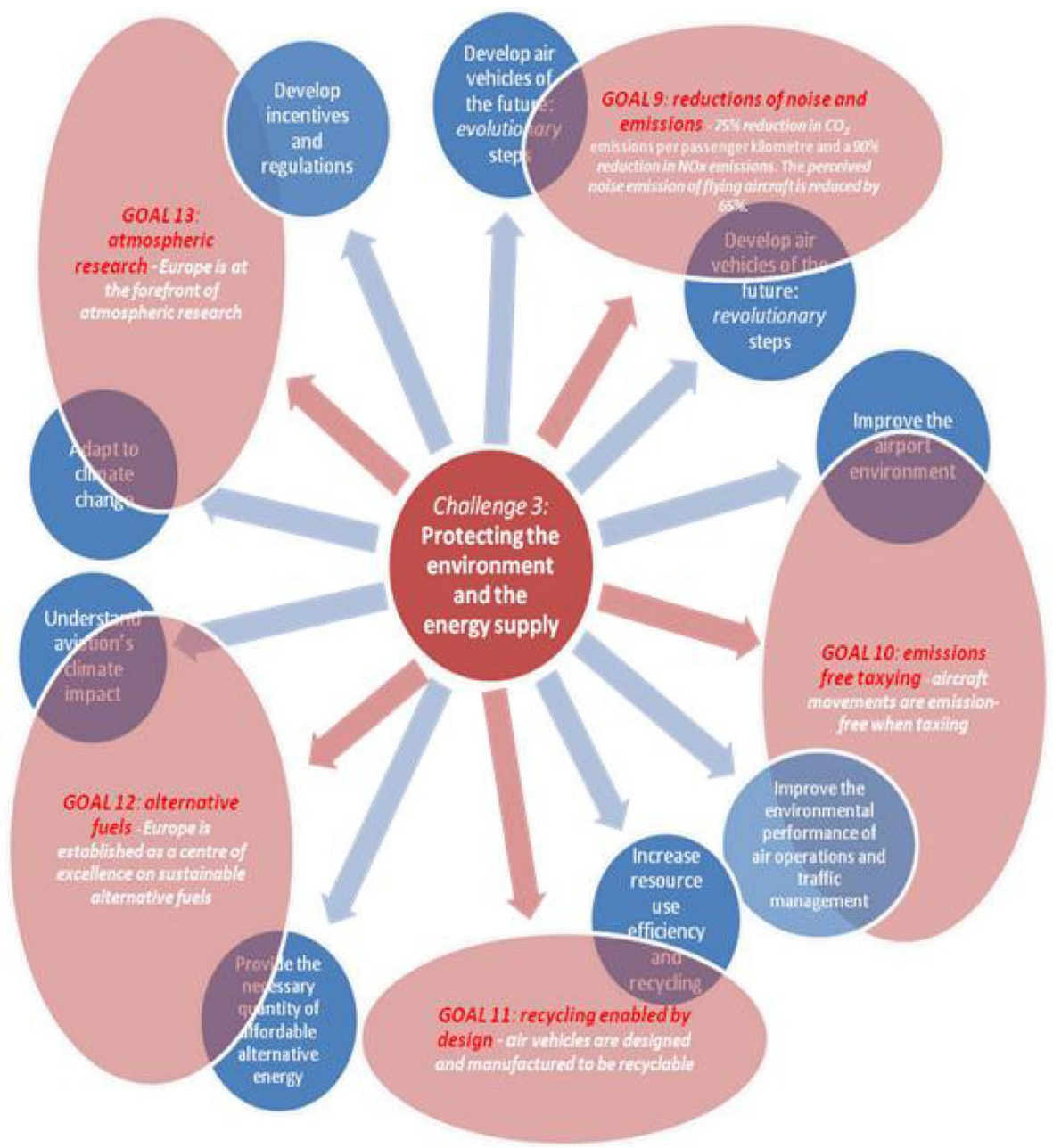


traffic management improvements in directions of vertical and lateral flight path optimization as close to the airport so as along the routes. Noise and emissions reductions can be achieved only if sufficient efforts are made for new technologies to mature; the transition from technology availability to technology uptake in a product or system is influenced by many factors; besides technology maturation, certification, sustainability and cost-effectiveness. There are also factors of a non-technological nature such as market expectations, new products or improvements being developed. Towards 2050 , the forecast growth in the aviation industry will drive the need to deliver revolutionary technology solutions at an increasing rate and secure the path to sustainable energy supplies that can displace today's fossil fuels to mitigate fully the potential impact on the atmosphere.

\section{Technology readiness level assessment}

One of the biggest challenges in managing technology is to properly choose which technologies to invest in and to know when technologies are ready or mature enough to be considered for a particular system/product. There are not plenty of metrics and tools developed to measure how ready a technology is. The most universally accepted methodology for assessing the upward slope of this curve is the Technology Readiness Level (TRL) scale-a systematic, metric-based assessment of how far technology development has progressed. TRLs are used to quantify the technology maturity status of an element intended to be used in a mission in accordance with Standard ISO 16290, 2013. The timeframe to 2050 leaves scope to mature what is now low TRL basic research to promising high TRL demonstrations and feasible solutions to meet FP2050 targets.

Complementarily to TRL a Commercial Readiness Level (CRL) scale is considered to serve as a framework for defining the spectrum of commercial maturity, from basic market research to full deployment, which is expected at the end of the project period. Following sections are arranged in accordance to the sequence of environmental objectives in the strategic document ACARE [2].

\section{Reduction of noise and emissions}

ACARE FP2050 goal 9: "In 2050 technologies and procedures available allow a $75 \%$ reduction in $\mathrm{CO}_{2}$ emissions per passenger- $\mathrm{km}$ and a $90 \%$ reduction in $\mathrm{NO}_{x}$ emissions. The perceived noise of flying aircraft is reduced by $65 \%$. These are relative to the capabilities of typical new aircraft in 2000". This goal covers noise and emissions. The distinction is made between engine and aerodynamic noise and local (impact on local air quality-LAQ) and global (impact on climate change) emissions.

Unfortunately, aircraft has a large number of noise sources. The major sources of engine noise are the fan and jet, and to a lesser extent, the compressors, combustor, turbine and bleeds (which may actually dominate at certain times during flight, Fig. 5). Airframe noise is generated by the airflow surrounding the moving plane. The main sources are the discontinuities of the aircraft structure, such as highlift devices, landing gear wheels (when extended), and trailing edges which lead to speed shearing (aircraft speed versus still air). A further source of noise arises from the interaction of the engines exhaust jet with the airframe. As a general rule, engine sources dominate on take-off while airframe noise dominates on approach (Fig. 5b).

There is potential for reducing noise by better component design and incremental improvements in existing technology, but it is not appropriate to detail all the possibilities here (Table 2 is used for illustrative examples). Instead, we highlight where new technological improvement is likely, and cases where an improvement in aircraft efficiency and gaseous emissions creates a new noise risk that will need to be addressed. However, they can be broadly classified as engine noise sources and airframe noise sources.

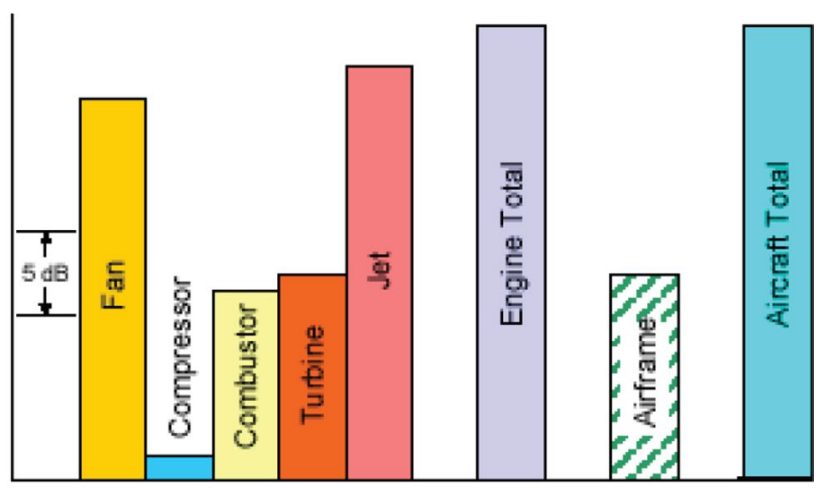

a)

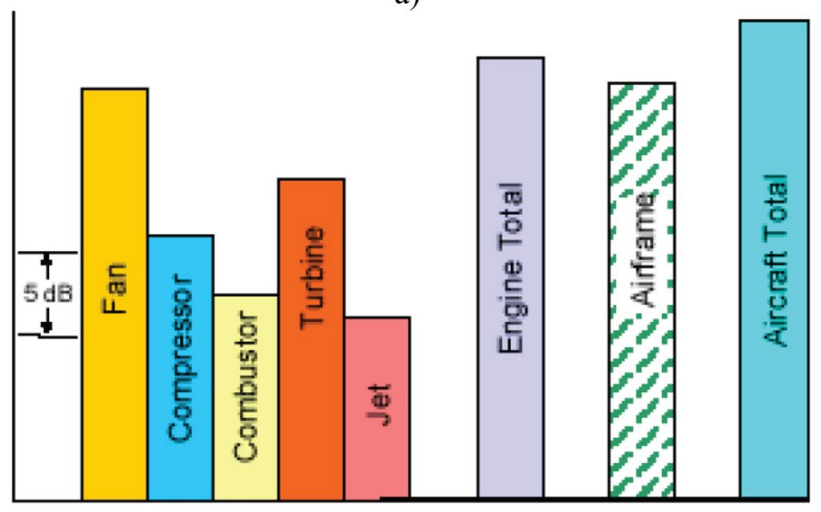

b)

Fig. 5 Sources of acoustic emission during: a takeoff; $\mathbf{b}$ landing [11] 
Table 2 Examples of potential noise reduction through component improvements. (based on data given in (CAEP/9 Meeting, 2013))

\begin{tabular}{|c|c|c|c|c|}
\hline Compo-nent & Technology & $\begin{array}{l}\text { Estimated } \mathrm{dB} \text { reduc- } \\
\text { tion on component } \\
\text { level }\end{array}$ & Timescale & Notes \\
\hline \multirow[t]{5}{*}{ Fan } & Rotor Sweep Stator Sweepand Lean & $2 \mathrm{~dB}$ & Near term & Current TRL 5 to 9 \\
\hline & Variable area nozzle & $2 \mathrm{~dB}$ & Near term & Complexity and weight issues \\
\hline & Liner improvements & $2-4 \mathrm{~dB}$ & Near term & $\begin{array}{l}\text { Manufacturing \& repair technologies need } \\
\text { to be developed. Integration with other } \\
\text { systems such as deicing }\end{array}$ \\
\hline & Active stators & Up to $8 \mathrm{~dB}$ & Near/long term & Highly complex weight and structural \\
\hline & Active blade control & Up to $20 \mathrm{~dB}$ & Near/long term & integrity issues \\
\hline \multirow[t]{2}{*}{ Jet } & Chevrons & $1-3 \mathrm{~dB}$ on $\mathrm{TO}$ & Near term & Potential fuel burn penalty \\
\hline & Fluid injections/microjets/ excitations & $1-3 \mathrm{~dB}$ & Near/long term & Highly complex \\
\hline \multirow[t]{3}{*}{ Landing gear } & Fairings & Up to $3 \mathrm{db}$ & Near term & $\begin{array}{l}\text { Weight penalty. } \\
\text { Maintenance access }\end{array}$ \\
\hline & Low noise design & Up to $5 \mathrm{db}$ & Near/long term & \\
\hline & Flow control & $1 \mathrm{~dB}$ & Near/long term & Weight penalty \\
\hline \multirow[t]{3}{*}{ High lift devices } & Slat track treatment & Up to $5 \mathrm{db}$ & Near term & Potential impact on L/D \\
\hline & Flap side edge treatment & Up to $5 \mathrm{db}$ & Near term & Potential impact on L/D \\
\hline & Low noise design & Up to $5 \mathrm{db}$ & Near/long term & Potential impact on L/D \\
\hline Core & Hot stream acoustic liners & $2-4 \mathrm{~dB}$ & Near term & \\
\hline
\end{tabular}

The major contributor to the reduction of engine noise has been the increase in the by-pass ratio (BPR) of turbofan engines, which also decreases fuel consumption, leading both to lower emissions and more favorable economics. The range of liners employed to attenuate noise will be significant in the near term. Specifically, lip liners (where the intake liner is extended around the lip of the nacelle intake) are feasible now that the problem of integrating them with the de-icing system has been overcome. Modern ceramics and improved manufacturing have made core exhaust liners possible, but the problem of high temperatures and a highly curved geometry must still be solved. Equally, ALM allows for varying the depth of nacelle liners to obtain a distribution of acoustic impedance that can be optimized for maximum attenuation or the use of radically new liner design.

Recommended Phased Approach to meet an approach by consensus based on expert's judgement, assessment of the TRL situation and results from the technology evaluation exercises has then been used to perform the 2015 progress assessment, coming up with updated progress achievement figures and formulating associated recommendations for future research. Goal 9 includes analysis of expected advances on noise reduction with Noise Reduction Technology, as well as the Noise Abatement Procedure contributions.

For example, NYSERDA TRL Calculator results for analysis and assessment of ACARE Challenge 3 Goal 9 achievements at $2^{\text {nd }}$ stage of the studies on PARE Project are shown in Fig. 6 grounding on the results of the $2^{\text {nd }}$ year PARE report [12]: $\mathrm{TRL}=8, \mathrm{CRL}=7$ for midterm 2020 goal;
$\mathrm{TRL}=3, \mathrm{CRL}=1$ for midterm 2035 goal. For 2050 goal a new SRIA and new goal definitions are necessary.

Aviation emissions of $\mathrm{CO}_{2}$ and $\mathrm{NO}_{\mathrm{x}}$ are produced by aircraft, support vehicles and ground transportation dominantly. The emissions from these sources fall into two categories: emissions that cause deterioration in LAQ and emissions that cause climate change. Current and future technological developments to achieve the challenging ACARE 2050 $\mathrm{CO}_{2}$ goal are essential to mitigate substantially the increase of aviation $\mathrm{CO}_{2}$, with realistic traffic growth assumption (Fig. 7).

A large part of the effort of the last decade was supported within EU Clean Sky, and within other European projects like LEMCOTEC, ENOVAL and E-BREAK. To achieve the 2050 goals, step changes in aircraft configuration and operation (including alternative energy sources) will be required-currently envisaged evolutions will not be sufficient [3]. ACARE runs three research projects to achieve these goals: $X$-Noise $E V$, which relates to aviation noise research, Forum $A E$, which relates to emissions research, and Core-Jet Fuel, which relates to alternative aviation fuels.

A new assessment was performed against ACARE $\mathrm{CO}_{2}$ and $\mathrm{NO}_{\mathrm{x}}$ goals and is summarized in Table 3. Each new generation of aircraft has substantial fuel efficiency improvements, first of all due to improvements in their engines $(\sim 80 \%$ of the fuel savings for the last generation of aeroplanes are due to improvements in their propulsion systems), - up to $20 \%$ more fuel efficient than the previous one. This is true for new generation aircraft (latest deliveries A220/A320neo/B737MAX for single-aisle category, 


\begin{tabular}{|l|l|}
\hline Category & Answer \\
\hline Technology & $\begin{array}{l}\text { Preliminary testing of technology components has begun, and technical feasibility has been established } \\
\text { in a laboratory environment }\end{array}$ \\
\hline Product Development & $\begin{array}{l}\text { Demonstration of a full scale product/system prototype has been completed in the intended } \\
\text { application(s) }\end{array}$ \\
\hline Product Definition/Design & $\begin{array}{l}\text { The product/system has been scaled from laboratory to pilot scale and issues that may affect achieving } \\
\text { full scale have been identified }\end{array}$ \\
\hline Competitive Landscape & $\begin{array}{l}\text { Competitive analysis to illustrate unique features and advantages of the product/system compared to } \\
\text { competitive products/systems has been completed }\end{array}$ \\
\hline Team & $\begin{array}{l}\text { Balanced team with technical and business development/commercialization experience running the } \\
\text { company with assistance from outside advisors/mentors }\end{array}$ \\
\hline Go-To-Market & $\begin{array}{l}\text { Market and customer/partner needs and how those translate to product requirements have been } \\
\text { defined, and initial relationships have been developed with key stakeholders across the value chain }\end{array}$ \\
\hline Manufacturing/Supply Chain & \begin{tabular}{l} 
Manufacturing process qualifications (e.g. QC/QA) have been defined and are in progress \\
\hline
\end{tabular} \\
Manufacturing/Supply Chain \\
Go-To-Market
\end{tabular}

Fig. 6 NYSERDA TRL Calculator results for analysis and assessment of ACARE Challenge 3 Goal 9 "Reduction of Noise and Emissions" [12]

Fig. 7 Global aviation $\mathrm{CO}_{2}$ forecast with ACARE assumption [13]

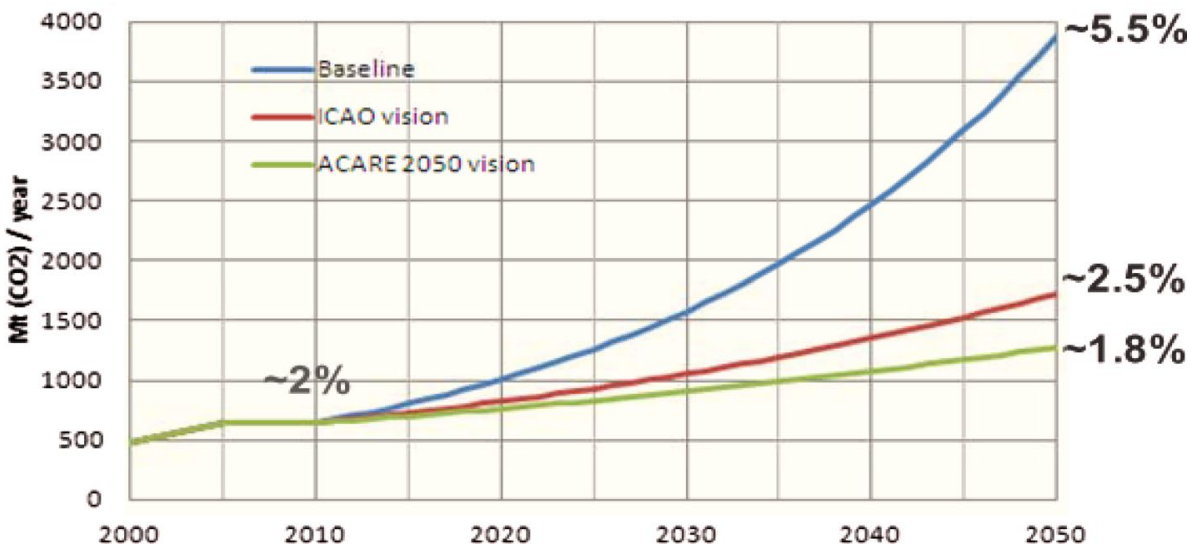

per annum fuel efficiency improvement [4] is unlikely to be met by 2050 if the evolutionary approach will be considered alone.

As example, $\mathrm{CO}_{2}$ Road-Map (Fig. 8) demonstrates the potential to accommodate significant aviation growth to 2050 without a substantial increase in $\mathrm{CO}_{2}$ emissions, through a better than doubling of carbon efficiency, namely in UK [14]. Through the adoption of newer, more efficient aircraft, sustainable fuels and better air traffic management and operational procedures, the aviation industry in the UK and in total EU will be able to accommodate significant growth through to 2050, including the effect of additional 




runway capacity in the East European States (for EU region), without a substantial increase in $\mathrm{CO}_{2}$ emissions.

A thorough analysis of the $\mathrm{CO}_{2}$ Road-Map at Fig. 8 shows it full correspondence with action areas for Challenge 3 of the ACARE perspectives at Fig. 4, confirming that an ACARE vision is also a basket of measures necessary to reach the Challenge 3 goals. Absent in ACARE document [2] market-base measures (defined by ICAO CORSIA standards [15]) must be considered as the main pusher of the new cleaner (and quieter) aircraft designs, appropriate infrastructure and SAF into the market, not being the economic instruments of management in aviation sector itself.

Although, there is no ACARE objective related to nonvolatile particles (nvPM), this is now a key environmental and regulatory concern, which requires appropriate mitigation solutions in technology (engine combustor technology and fuel composition). It is evident gap in current SRIA FP2050, while a new ICAO standard for nvPM engine emission instead of smoke number standard was adopted by ICAO Council in March of 2020.

\section{Aircraft electrification nowadays and in future}

Although, there is no ACARE objective related to non-volatile particles (nvPM), this is now a key environmental and regulatory concern, which requires appropriate mitigation solutions in technology (engine combustor technology and fuel composition). It is evident gap in current SRIA FP2050, while a new ICAO standard for nvPM engine emission instead of smoke number standard was adopted by ICAO Council in March of 2020.

Stepwise development to meet environmental targets in aviation sector-evolutionary and revolutionary technology solutions to be researched and implemented complementarily - provides a necessity to formulate mid-term and longterm goals, especially driven by climate change impact of aviation. For example a concept of More Electric Aircraft covers a number of technologies to be introduced in aircraft control in flight during nearest decades (mid-term goals for emission reduction and energy supply). Full Electric Aircraft concept is considered as a subject of deep concern for the last decade (long-term goals) in progress to 2050 achievements. Complexity of the Challenge 3 towards 2050 creates the conditions when/where new evolutionary and revolutionary technology achievements are expected in all spheres of aviation sector-aircraft design and manufacturing, their operation and maintenance, including airport and ATC infrastructure and procedures.

New technologies will bring change, challenge and opportunity, too. This will comprise harnessing the benefits of changes to technology embedded onto aircraft, including 


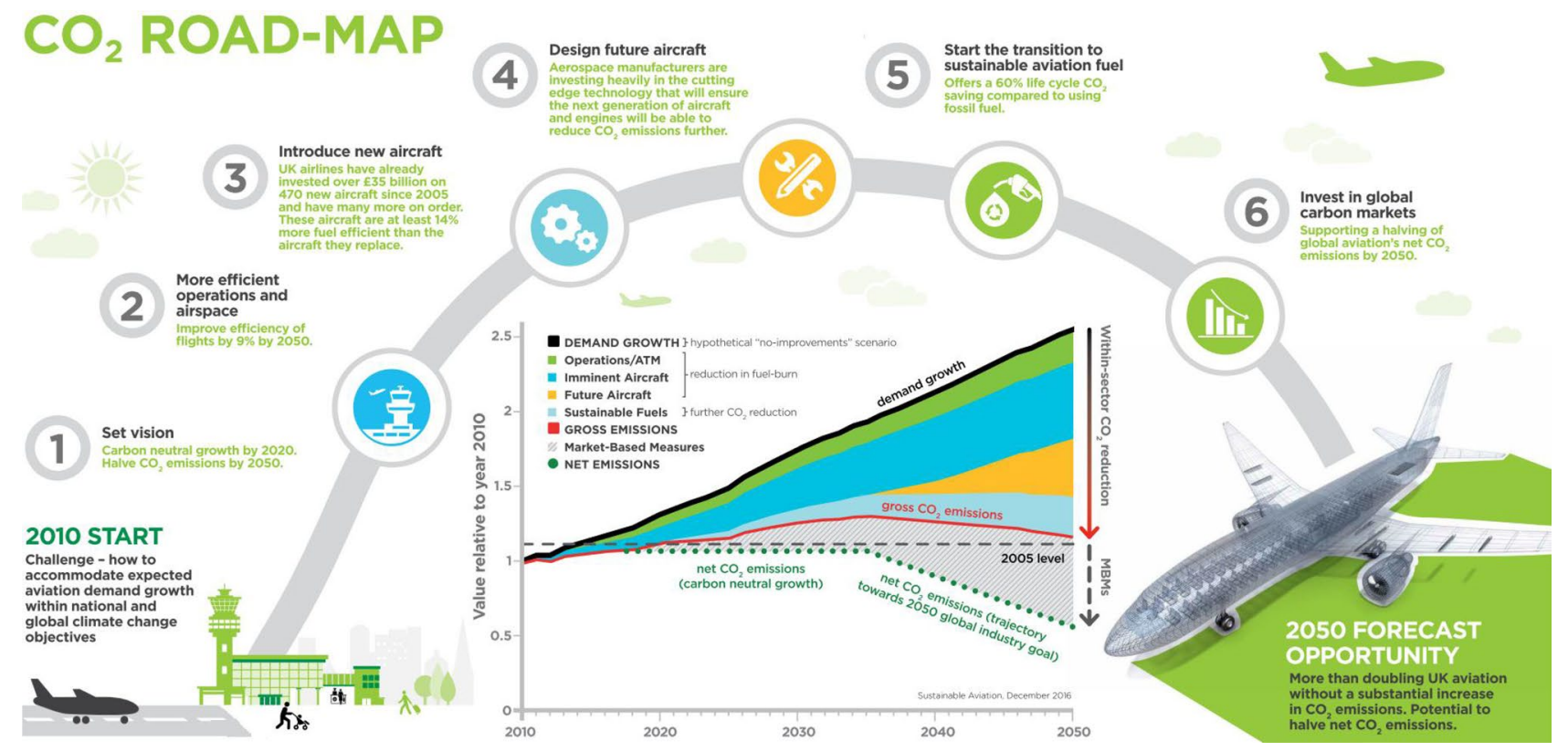

Fig. 8 The goals and action areas for Challenge 3 of the ACARE perspectives [14]

the coming revolution in full-electric (use batteries as the only source of propulsion power on the aircraft) or hybrid electric power for aircraft and other disruptors like the possibilities of urban air mobility vehicles. Electrification of aircraft has the potential to revolutionize the aerospace and aviation industries. Up to date a number of new programs were launched for the four types of aircraft-General Aviation/Recreational Aircraft, Urban Air Taxis (vertical take-off and landing aircraft), Regional/Business Aircraft and Large Commercial Aircraft. Most of them target an entry-in-service date between 2020 and 2030 (if COVID-19 will not impact the progress sufficiently), although some are already commercially available. The design and usage optimization of electric propulsion architectures over a range of aircraft designs and series of missions is complex (Fig. 9).

Electrical propulsion is finally on the map: almost 100 electrically propelled aircraft are already in development globally. Most developments are currently working on general aviation (ATS) or urban air taxi architectures (UAM). Given the current state of technological advancement, this is unsurprising as these smaller architectures require less total power and are less limited by constraints such as battery and motor gravimetric densities.

Considering a time span up to 2035 , meaning +20 years in Fig. 9, we can see how full electric power could be employed only in general aviation and in some commuter or UAS applications, while partially electric propulsion would be needed to power commuters and regional propeller-driven airplanes. Turbofan aircraft would at most benefit from assisted electric power, provided that a trade-off could be made between engine mass increase and fuel consumption, noise and pollutant emissions decrease; only more electric aircraft tendency is thus expected.

Moving to a larger time span, up to 2050 ( +35 years), we can expect to have advanced enough batteries to grant high performance to enable full electric power sources even to standard 200-300 PAX airliners (A320/B737 category), Fig. 9.

Concerning fuel burn reduction, one can observe a potential trend for commercial aircraft, Fig. 10. Taking year 2000 as a reference, as considered by FP2050 SRIA, it can be expected an improvement due to hybrid electro-mobility starting around 2025, with fuel saving around $25-30 \%$ due to advanced turbofan studies (ultrafans with $\mathrm{BPR}=15$ and higher), while further improvements are subjected to large uncertainties. This possibility to extend this technology to large aircraft by 2050 is affected by heavy uncertainty and requires large improvements in terms of power-to-weight ratio of electric motors and electro-mechanical conversion, cooling systems, wiring and, of course, on batteries.

\subsection{Emissions free taxiing at airports}

More than 200 members of ACI Europe (the trade association for European airports) have committed to produce net zero carbon emissions by 2050 . The taxiing of aircraft on engine power and the use of auxiliary power units (APU) on the ground can be significant contributors to emissions at airports and also generate noise. UK cross-industry group Sustainable Aviation found that $30 \%$ of total $\mathrm{CO}_{2}$ emissions at Heathrow Airport came from aircraft taxiing and the use of auxiliary power units (APUs) [14]. 


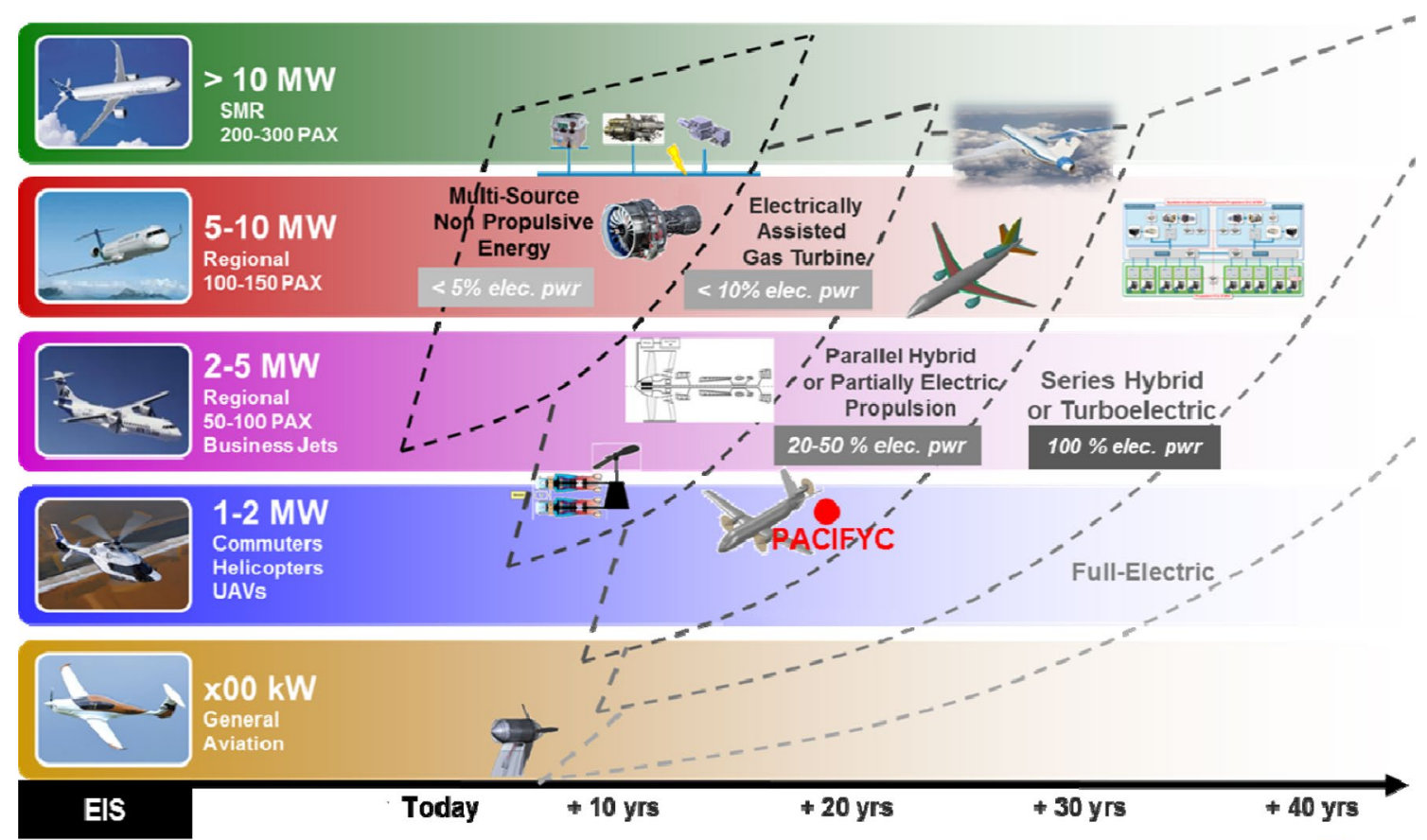

Fig. 9 Trends of possible aircraft hybrid architectures at different installed power, from [16]

Fig. 10 Fuel burn reduction expectation with respect to year 2000 [17]

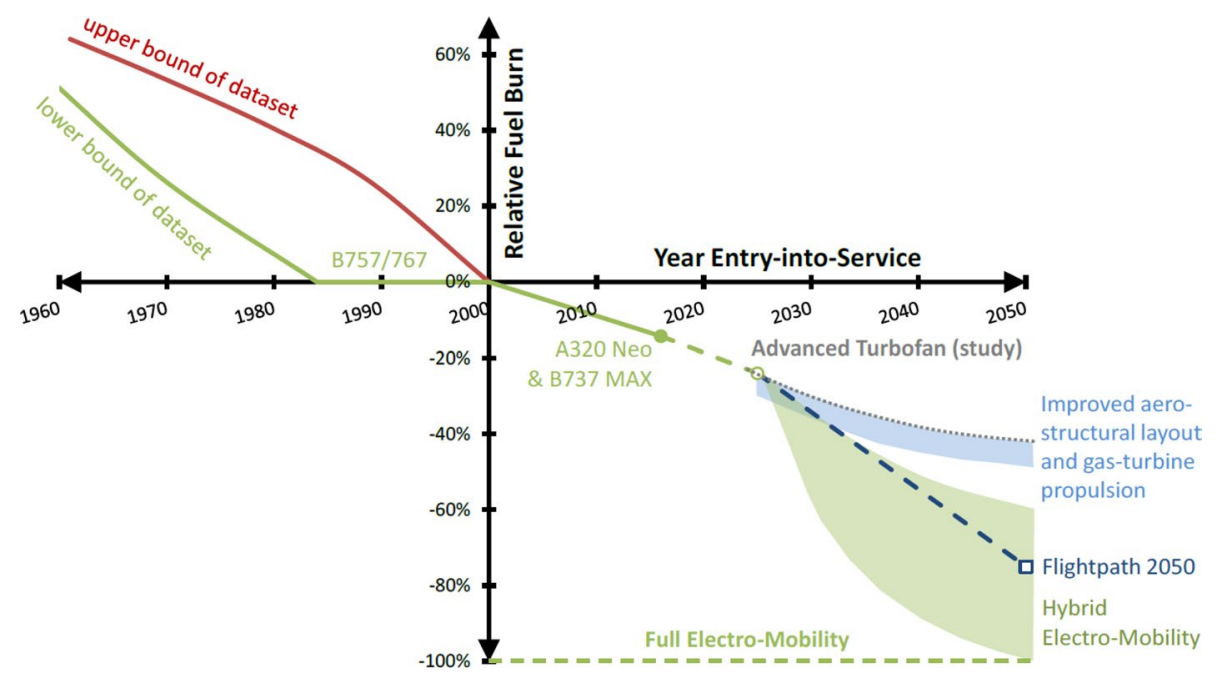

Savings of 100,000 tonnes of $\mathrm{CO}_{2}$ per year have been calculated at Heathrow from reduced engine taxiing and APU substitution.

On a global level, IATA has estimated a $\mathrm{CO}_{2}$ savings potential in the order of 6 million tonnes annually. The most obvious way to achieve ACARE FP2050 Goal 10 is to use electric towing vehicles. There are technical aspects like ensuring compatibility of towing brackets and sufficient traction power. Also infrastructure aspects with recharging facilities for a fleet of electric towing vehicles.

Electric landing gear drive equipped with traction motors can provide taxi capability without the use of main engines or tractor. WheelTug was the first company to demonstrate the operation of an on-board electric taxiing system in 2005. An example of external ground propulsion system is TaxiBot-semi-autonomous hybrid electric tractor, a system developed by Israeli Aerospace Industries. Safran has generated real industry buzz by offering the first electric taxiing solution, with an electric motor in the landing gear, powered by the APU, so that pilots no longer have to use their jet engines for taxiing. This innovative solution is now being developed with Airbus for the A320neo/ceo. The target date for entry into service is 2022 . According to a study carried out with airlines, this system makes a lot of sense at 
busy airports with long taxiing times, as well as for carriers that operate a number of daily shuttle flights. With this new technology, they can reduce not only their operating costs, but also their environmental footprint.

On-board solutions are the most suitable for narrow-body aircraft, which have many flight cycles during the day with high taxiing time. For wide-body aircraft, the fuel savings during taxiing would be canceled during the flight phase due to having extra on-board weight. Therefore, one possible scenario to be foreseen is a mixture of the two types: on-board for narrow-bodies and external systems for widebodies aircraft.

The current preferred battery technologies for ground movements at the airport or on the airfield and in the aircraft itself are the lead - acid and the nickel_-cadmium (Ni-Cd) batteries. However, since these batteries are technically exhausted, no significant improvement in terms of energy density, cycle life, calendar life, etc. is expected; there is a shift to lithium-ion ( $\mathrm{Li}$-ion) technology in the aviation industry, being that Li-ion chemistry offers a large variety of materials and cell architectures, which enables the possibility to design high-power as well as high-energy systems.

In general, regarding Li-ion batteries, an increase in the energy density, with state-of-the-art chemistry, could be mainly achieved by optimizing the form factor and the cell production process. Nevertheless, even if the current chemistry has proven itself, efforts are still to be made to increase the energy density as well as other key performance parameters to meet future requirements. NYSERDA calculator results for analysis and assessment of ACARE FP2050 Goal 10 "Emissions Free Taxiing at Airports" achievements: $\mathrm{TRL}=3, \mathrm{CRL}=2[12]$.

\section{Design and manufacture bearing in mind recycling}

ACARE FP2050 goal 11: "Air vehicles are designed and manufactured to be recyclable".

Recycling of aircraft parts depends mostly on the materials used and also on the fabrication process. The choice of materials for an aircraft is subject to a considerable set of constraints related to performance, weight, availability, cost, ease of manufacture and maintenance, durability and resistance to hostile environments. Adding the recycling ability is an additional constraint which can bring benefits in several of other areas; it may require consideration of materials not previously used in the aerospace industry and take advantage of the major progress made synthetizing new substances with tailor-made properties (graphene).

Recycling aircraft parts depends mostly on the materials used and also on the fabrication process. The choice of materials for an aircraft is subject to a considerable set of constraints related to performance, weight, availability, cost, ease of manufacture and maintenance, durability and resistance to hostile environments. Adding the recycling ability is an additional constraint which can bring benefits in several of other areas; it may require consideration of materials not previously used in the aerospace industry and take advantage of the major progress made synthetizing new substances with tailor-made properties (graphene). There is a need for effective materials extraction and separation technologies, worthwhile end-use applications for the recovered materials as well as an attractive business model for aircraft recyclers. Only when all of these conditions are united can the aircraft recycling industry truly take-off in Europe.

Recent technological advances in the field of power electronics, fault-tolerant architecture, electro-hydrostatic actuators, flight control systems, high density electric motors, power generation and conversion systems have ushered the era of the more electric aircraft. A small size, high-energy density (more than $100 \mathrm{~W}$-hour per kilogram $(\mathrm{Wh} / \mathrm{kg})$ ) battery is the need of the aircraft industry as a $10 \mathrm{~kg}$ decrease in the weight of aircraft will result in the savings of 17,000 tons of fuel and 54,000 tons of carbon dioxide emission per year for all air traffic worldwide. The reduction in battery weight is also profitable in terms of cost. The life duration of an aircraft battery depends on various factors such as number of operating hours, ambient temperature, start frequency and on-board charge. It is therefore difficult to determine in advance how long the expected life of a battery will be in the real situation.

It is recommended that a comprehensive assessment of materials used in aircraft production is made and that recyclable alternatives and related issues of availability, ease of use, certification, maintenance and cost are assessed. NYSERDA calculator results for analysis and assessment of ACARE FP2050 Goal 11 "Design and manufacture bearing in mind recycling" achievements: TRL $=8, \mathrm{CRL}=4$ [12].

\section{Sustainable alternative fuel sources}

ACARE FP2050 goal 12: "Europe is established as a center of excellence for sustainable alternative fuels, including those for aviation, based on a strong European energy policy".

The supply of fuel alternative to kerosene is subject to major efforts by large consumers like the US Air Force. The consumer base is more diversified in the airline industry but it is no less important due to the large number of flight hours. Although airlines have been willing to test new fuels a coordinated effort must be done far upstream to: (i) consider a variety of sources of fuel, that do not interfere with food production and whose environmental impact is neutral or positive (waste disposal); (ii) establish 
the technical feasibility to meet all applicable quality and safety standards and certification requirements; (iii) assess the economic and environmental feasibility of large-scale sustained production, distribution and use.

For example hydrogen is a clean fuel that produces only water vapor by combustion; however the quantities produced and altitudes should be considered as for contrails. Hydrogen has a low volume power density and requires cryogenic conditions; water is an abundant source of hydrogen but its separation by hydrolysis is energyconsuming. Hydrogen-powered aircraft are expected feasible and may appear on intra-European routes around 2040. At the opposite extreme some algae have high yields per unit area of culture; the full processing chain up to flight grade fuel needs to be considered. In between other options exist, making multiple sources of aviation fuel all the more desirable.

The use of the biofuel has been tested in two series of flights. The first series of 18 long-haul flights from Amsterdam to Aruba, on an Airbus A330-200 (carrying around 4,500 passengers informed about the project) was performed using biojet fuel blend in one engine to compare the performance of the two engines. No significant performance differences were noted, but that the water accumulated in the tanks during flights can be lowered using the synthetic fuel, reducing the maintenance frequency and costs. The second series of 80 short-haul flights, from Oslo to Amsterdam, on an Embraer E190, carrying about 8,000 passengers, using the camelina biojet blend in both engines, confirmed the no detrimental effects on operation with similar or slightly better fuel consumption and, no variation in fuel gauging systems.

The flight series were complemented with a series of lab-based emission measurements using a testbed APU. APU emissions tests were completed for the two ITAKA fuel batches and baselined against a standard fossil Jet fuel: performance parameters were as expected quite similar, fuel consumption decrease up to $1 \%$ (saving fuel and $\mathrm{CO}_{2}$ emissions), and the emitted particulate matter (PM) was decreased up to a 50\% for a 50:50 fuel blend. PM emissions are the major air quality concern that are linked with a significant number of premature deaths across Europe. High paraffinic fuels such as HEFA biojet could significantly help to reduce the impact of this pollutant in the vicinity of airports. The information obtained has been supplied to the ICAO for the development of future standards for aircraft engines. At present, using biofuel in aviation is not of economic benefit because it is more expensive than the conventional aviation kerosene. As predicted by the experts, the oil prices can fall in already in the near future. This being the situation, one of the measures can be the legislative obligations to use in one or another proportion the purer, but simultaneously the more expensive alternative types of fuels.
ACARE also runs the research project entitled Coordinating research and innovation of Jet and other sustainable aviation Fuel (Core-JetFuel). European aviation specifically must guarantee that, in 2050. It is recommended that a comparative study of potential alternative fuels, their availability in the required large quantities and the feasibility and cost of large-scale production, distribution and use is performed. NYSERDA calculator results for analysis and assessment of ACARE FP2050 Goal 12 "Sustainable Alternative Fuel Sources" achievements: TRL $=7, \mathrm{CRL}=3$ [12].

\section{Atmospheric research, weather and the environment}

ACARE FP2050 goal 13: "Europe is at the forefront of atmospheric research and takes the lead in the formulation of a prioritized environmental protection plan and the establishment of global environmental standards".

Atmospheric hazards have been a safety concern throughout the history of aviation and are addressed in the ACARE goal 15. A better modelling and understanding of atmospheric phenomena can reduce disturbances of air traffic management (ACARE goal 5) and allow an increase of runway capacity at airports (ACARE goal 1). As major users of the airspace aviation can contribute to the monitoring of the atmosphere and to the establishment and implementation of global environmental standards. The monitoring of the atmosphere is performed by a vast array of earth and satellite sensors, plus specialized weather aircraft like those used by National Oceanographic and Atmospheric Administration in the USA to fly through tropical storms and collect in-situ atmospheric data. The data transmission capabilities of airliners in modern ATM systems could be used not only for traffic proposes but also to collect atmospheric data in support of environmental standards and policies. It is in the interest of airlines to preserve their flight environment and if appropriate some of the millions of flight around the world could be a source of in-situ measurement and monitoring.

There are several methods to monitor the atmosphere, such as: routine ground-based measurements (made by ground-based sensors-land-based and buoys); systematic aircraft measurements (made by aircraft and balloons); and satellite measurements (made by space-borne sensors).

Changes to temperature, precipitation, and storm patterns are all expected in the near-term, certainly by 2030 . The impacts of sea-level rise are more gradual and not expected until later in the century. However, more frequent and intense storm surges will have an earlier impact on European aviation, reducing capacity and increasing delay.

Currently, there are several European initiatives and projects that have as main objective monitoring the atmosphere through satellite and airborne instrumentation, which are: 
- Copernicus project, previously known as the Global Monitoring for Environment and Security;

- Constellation Observing System for Meteorology, Ionosphere and Climate project;

- Advanced Satellite Aviation Weather Products initiative;

- European Organisation for the Exploitation of Meteorological Satellites; In-service Aircraft for a Global Observing System project.

It is recommended that regular airliner flights are used to collect in-situ atmospheric data, which should further be processed to have near real-time knowledge of conditions along flight routes. NYSERDA calculator results for analysis and assessment of ACARE FP2050 Goal 13 "Atmospheric Research, Weather and the Environment" achievements: $\mathrm{TRL}=3, \mathrm{CRL}=3[12]$.

\section{Conclusion}

In conclusions there are few current recommendations formulated for ACARE FP2050 Challenge 3 Goals: 1) Support a broad research effort to reduce aircraft noise (a) at the source (b) through operating procedures and (c) taking into account its psychoacoustic effects and other kinds of impact; 2) Besides struggling with short term solutions to an increasingly pressing noise problem a modest effort should be made towards a long-term definitive solution: aircraft in audible outside airport boundaries; 3 ) To formulate a set of trade-offs between different types of emissions $\left(\mathrm{CO}_{2}, \mathrm{NO}_{\mathrm{x}}\right.$, $\mathrm{PM}$ and water vapor) in local airports and global cruise flights; 4) Besides struggling with short-term emissions problems put a modest effort towards a long-term definitive solution: the hydrogen powered and electric powered aircraft are among the possible solutions (and associated supporting airport infrastructure). Additional to them expected drastic improvement in aircraft configuration in direction to reduce operational weights and to rise lift-to-drag performances intended to all classes of the aircraft including BWB implementation for basic aeroplane design $[9,10]$.

Evident gaps were found also concerning the absence of the strategic targets for nvPM emission reduction in aviation sector, necessity for reformulation of global impact from the inventory assessment to real climate change value like the ICAO currently reconsider this strategic goal in CAEP work [4]. The elaboration of CORSIA documents still continue in ICAO/CAEP and the voluntary stages of the States involvement into this global program is very close [15]. The successful solutions for Europe will be dependent of how Europe Green Deal (2019) directive will co-inside with ICAO environmental policy. For noise subject it will be important to formulate the goal for supersonic aircraft, which is returning to operation during next decade, and for
UAS, which are attractive expansion of air transportation in UTM and UAM systems in near future.

Acknowledgements Acknowledgements to EC PARE project (Perspectives for the Aeronautical Research in Europe) № H2020-MG-2017-SingleStage-RTD-MOVE-769220.

\section{Declarations}

Conflict of interest The authors declare that they have no competing interests. This article is prepared on results of presentation of this material at AEC-2020 conference in Bordeau, where a PARE session was organized. Coordinator of the PARE project even included in report for 2020 year that we sent a draft to CEAS Aeronautical Journal for review and publication.

\section{References}

1. Strategic research and innovation agenda-2017 update. Vol. 1. Delivering Europe's vision for aviation. Advisory council for aviation research and innovation in Europe (ACARE), DLR, Cologne, 2017, Publ. (2017). https://www.acare4europe.org/sites/acare 4europe.org/files/document/ACARE-Strategic-Research-Innov ation-Volume-1.pdf. Accessed 25 June 2021

2. Flightpath 2050. Europe's vision for aviation report of the high level group. Policy. EU Directorate-General for research and innovation, Directorate general for mobility and transport on aviation research. Luxembourg: Publications office of the European union, 2011, Publ. (2011). https://ec.europa.eu/transport/sites/default/ files/modes/air/doc/flightpath2050.pdf. Accessed 25 June 2021

3. Industry Monitor 214-November/December 2019, EUROCONTROL Statistics and forecast service, Publ. https://www.euroc ontrol.int/publication/industry-monitor-november-december2019. Accessed 25 June 2021

4. ICAO Resolution A40-17. Consolidated statement of continuing ICAO policies and practices related to environmental protection-General provisions, noise and local air quality. Resolutions adopted by the assembly 40th SESSION, Montréal, October 2019, provisional edition, October 2019, Publ. (2019). https://www.icao. int/environmental-protection/Documents/Assembly/Resolution A40-17_General_provisions_noise_and_LAQ.pdf. Accessed 25 June 2021

5. National Science and Technology Council: National aeronautics research and development plan. National Science and Technology Council, Washington (2010)

6. ASCENT Project 037 CLEEN II Technology Modeling and Assessment: Continuous lower energy, emissions, and noise (CLEEN) program. Georgia Institute of Technology, Georgia (2015)

7. EUROPEAN AVIATION IN 2040. Challenges of Growth, 2018. Summary report. European organisation for the safety of air navigation (EUROCONTROL), June 2018, Publ. (2018). https:// www.eurocontrol.int/sites/default/files/content/documents/offic ial-documents/reports/challenges-of-growth-2018.pdf. Accessed 25 June 2021

8. European Aviation Environmental Report 2019. www.easa. europa.eu/eaer. Accessed 25 June 2021.

9. Page, M.A., Smetak, E.J., Yang, S.L.: Single-aisle airliner disruption with a single-deck blended-wing-body ICAS-2018, International congress of the aeronautical sciences proceedings, Belo Horizonte, Brazil, September, 2018, ISBN: 978-3-932182-88-4. 
https://www.icas.org/ICAS_ARCHIVE/ICAS2018/data/preview/ ICAS2018 0390.htm

10. Yang, S.L., Page, M.A., Smetak, E.J.: Achievement of NASA New Aviation Horizons N+2 Goals with a Blended-Wing-Body $\mathrm{X}$-Plane Designed for the Regional Jet and Single-Aisle Jet Markets. Conference: 2018 AIAA Aerospace Sciences Meeting, Kissimmee, Florida, USA, January 2018. https://doi.org/10.2514/6. 2018-0521

11. Leylekian, L., Lebrun, M., Lempereur, P.: An overview of aircraft noise reduction technologies. AerospaceLab J (2014). https://doi. org/10.12762/2014.AL07-01

12. PARE D1.2 2019. State-of-the-art Flightpath 2050 goals. Deliverable under WP1 of the PARE project, EC Grant agreement $\mathrm{N}^{\circ}$ 769220, Horizon 2020. https://www.pareproject.eu/publications. Accessed 29 May 2018

13. FORUM-AE, 2015. Mid-term synthesis. D4.14, Forum-AE coordination \& support action, FP7-605506, Issued on 31st July 2015. Publ. http://www.forum-ae.eu/system/files/forum-ae_mid-term synthesis_july_2015_0.pdf. Accessed 19 December 2019

14. Sustainable Aviation. Progress Report 2015-2017. A cleaner, quieter, smarter. https://www.sustainableaviation.co.uk/progr ess-reports/. Accessed 25 June 2021

15. ICAO Annex 16 to the Convention on international civil aviation—environmental protection: Volume IV—Carbon offsetting and reduction scheme for international aviation (CORSIA), Ed. 1, 2018, Publ. https://elibrary.icao.int/home/product-details/229739. Accessed 25 June 2021

16. Isikveren, A.T., Fefermann, Y., Maury C.: Long-term hybridelectric propulsion architecture options for transport aircraft, conference: greener aviation, brussels 2016, Publ. (2016). https:// www.researchgate.net/publication/309025157_LONG-TERM_ HYBRID-ELECTRIC_PROPULSION_ARCHITECTURE_ OPTIONS_FOR_TRANSPORT_AIRCRAFT. Accessed 25 June 2021

17. Hornung, M., Isikveren, A.T., Cole, M.,, Sizmann, A.: Ce-Liner - Case Study for eMobility in Air Transportation s, Conference: 2013 Aviation Technology, Integration, and Operations Conference, Publ. (2013). https://www.researchgate.net/publication/ 268470882_Ce-Liner_-_Case_Study_for_eMobility_in_Air_ Transportation. Accessed 25 June 2021

Publisher's Note Springer Nature remains neutral with regard to jurisdictional claims in published maps and institutional affiliations. 